Original Paper http://ajol.info/index.php/ijbcs http://indexmedicus.afro.who.int

\title{
Geohelminth infection, anemia, and malnourishment in Bawa, Cameroon after ten years of intervention by the Bawa Health Initiative
}

\author{
D. J. RICHARDSON ${ }^{1,2}$, J. A. GROSS ${ }^{1}$, P. TSEKENG ${ }^{1,3}$ and B. DONDJI ${ }^{1,4 *}$ \\ ${ }^{1}$ Bawa Health Initiative, P.O. Box 432, Wallingford, Connecticut 06492. \\ ${ }^{2}$ Department of Biological Sciences, Quinnipiac University, 275 Mt. Carmel Avenue, Hamden, \\ Connecticut 06518. \\ ${ }^{3}$ Wakenut Medical Services, Yaoundé Cameroon, Africa. \\ ${ }^{4}$ Laboratory of Cellular Immunology and Parasitology, Department of Biological Sciences, Central \\ Washington University, 400 East University Way, Ellensburg, Washington 98926. \\ *Corresponding author; E-mail:dondjib@cwu.edu
}

\section{ACKNOWLEDGEMENTS}

Financial support of this work was provided by the Bawa Health Initiative, Wallingford, Connecticut, USA. The World Health Organization and the Cameroon Ministry of Public Health are also acknowledged for providing us with the albendazole.

\begin{abstract}
The Bawa Health Initiative (BHI) was established in 2005 with the goal of initiating a comprehensive public health care program in Bawa, a rural village in the West region of Cameroon. Interventions undertaken include a comprehensive helminth control program, provision of water filters, sanitary latrines, insecticidetreated bed nets, and a health education program. Data gathered from citizens of Bawa during Dec 2017, were obtained from the Sophie Awounke Community Health Center in Bawa, Cameroon. These data including prevalence of geohelminth infection, morphometric data, and hemoglobin concentrations were compared to data gathered in previous surveys conducted by BHI in 2007 and 2010 to assess the effectiveness of interventions implemented by the organization. All metrics indicate substantial improvement in the overall health of the citizens of Bawa, evidenced by decreases in the occurrence of anemia, prevalence of malnourished, undernourished and stunted individuals and in the prevalence and intensity of geohelminths. These data strongly suggest that public health interventions implemented by BHI have been effective in reducing the burden of disease and increasing the overall well-being of the citizens of Bawa, Cameroon and surrounding villages.

(C) 2020 International Formulae Group. All rights reserved.
\end{abstract}

Keywords: Ascariasis, trichuriasis, hookworm infection

\section{INTRODUCTION}

The Bawa Health Initiative (BHI) is a 501(c)3 non-profit organization established in 2005 with the goal of initiating a comprehensive public health care program in the village of Bawa and surrounding areas located in the Menoua Division, West Region of Cameroon, Africa. For geographic, 
demographic, and climatological descriptions of Bawa and surrounding regions, refer to Smith (2007), Callahan (2010), Tchuinkam et al. (2010), Richardson et al. (2011a, b) and Onana et al. (2019). Included among the interventions implemented by BHI was a comprehensive helminth control program initiated in 2008, consisting of biannual treatments, with single $400 \mathrm{mg}$ doses of albendazole being distributed to all citizens of Bawa over the age of 2 years, excepting pregnant women. In addition, during the summers of 2007 and 2008, insecticide treated bed nets were distributed to all residents to minimize transmission of malaria. The Village Health Committee of Bawa and BHI has continuously maintained an ongoing program of education stressing the importance of continual proper usage of bed nets, including inspection and replacement of nets as necessary. Other public health measures undertaken by BHI in Bawa include the installation of biosand water filters in all family compounds and, beginning in 2014, a program of installation of sanitary latrines since provision of adequate sanitation is essential for human health and well-being (Letah Nzouebet et al., 2019). Richardson et al. (2011b) provided a detailed description of early interventions in Bawa and surrounding villages.

On $4^{\text {th }}$ December 2017, the Sophie Awounke Community Health Center was opened in Bawa. Over a four-day period, all residents of Bawa were asked to visit the clinic to receive a basic health examination. Stool exams were conducted, and basic morphometric data and hemoglobin concentrations were measured as part of this survey. The overall results of these examinations are presented herein and compared to earlier data. The objectives of this study were to assess the efficacies of public health interventions undertaken by BHI over the past ten years and to provide a benchmark for comparison to assess future effectiveness of the program.

\section{MATERIALS AND METHODS}

A survey of geohelminth infection was conducted according to Richardson et al. (2011a,b) as follows: Between $4^{\text {th }}$ December and $7^{\text {th }}$ December 2017, 210 stool samples were examined for the presence of the geohelminths Ascaris lumbricoides, Trichuris trichiura, and hookworms using the Kato-Katz technique and when sample volume permitted fecal flotation as described by Richardson et al. (2008). All slides were examined within one hour of preparation. Data were divided among age groups and genders as follows: 0-5 years (pre-school children), 6-15 (school-aged children), 16-59 (adults), and $\geq 60$ (senior adults). All samples were examined using the Kato-Katz technique and approximately 150 samples were examined using fecal flotation. Utilization of fecal flotation failed to reveal any infection not detected by Kato-Katz, thus all data reported in results were determined by the Kato-Katz technique. Additionally, future surveys conducted on this population for comparative purposes need not utilize fecal flotation. Infection intensity was categorized based on Montressor et al. (2002) as described by Richardson et al. (2011b).

Assessment of general health and nutritional status of 247 individuals was conducted by observation of morphometric data [height, weight, and body mass index (BMI)] and hemoglobin levels according to Richardson et al. (2011b) as follows: Height was recorded in $\mathrm{cm}$ and weight was recorded in $\mathrm{kg}$. Body mass index was calculated according to the World Health Organization (WHO) (2006) using the formula $\mathrm{BMI}=$ mass $(\mathrm{kg}) /$ [height $(\mathrm{m})]^{2}$. Individuals with a BMI $\leq 2$ standard deviations (SD) from the WHO growth standards were considered malnourished and individuals with a $\mathrm{BMI} \leq 3$ $\mathrm{SD}$ were categorized as exhibiting severe acute malnutrition following universal standards calculated by WHO for children $\leq 5$ years (WHO, 2006; WHO and UNICEF, 2009) and adolescents 6-19 years (de Onis et al., 2007). 
Nutritional status of adults ( $\geq 20$ years) was assessed according to WHO guidelines (WHO, 1995) such that adults with a BMI $<18.5$ were considered malnourished. Children and adolescents 5-19 years exhibiting height for age $\leq 2 \mathrm{SD}$ and $\leq 3 \mathrm{SD}$ from the WHO standards were considered stunted and severely stunted, respectively (Caulfield et al., 2006). Children, $\leq 10$ years-of-age, exhibiting weight for age $\leq$ $2 \mathrm{SD}$ and $\leq 3 \mathrm{SD}$ from the WHO standards were considered underweight and severely underweight, respectively. Children, 2-5 years-of-age, whose weight for height was $\leq 2$ SD from WHO standards were considered wasted (Caulfield et al., 2006).

Hemoglobin concentration was recorded in $\mathrm{g} / \mathrm{dl}$ from a drop of blood procured by dermal puncture. Individuals were categorized as not anemic, anemic, or severely anemic according to standards established by Stoltzfus and Dreyfuss (1998). The hemoglobin concentration ( $\mathrm{g} / \mathrm{dl})$ cut-off for being considered anemic for children under 5 years was 11.0. For children 5-11 years the cutoff was 11.5, for women the cutoff was 12.0, and for men the cutoff was 13.0. Individuals with a hemoglobin concentration $\leq$ 7 were considered severely anemic. These represent conservative estimates because the standards were established assuming hemoglobin concentration at sea level (Stoltzfus and Dreyfuss, 1998) and the numbers were not adjusted for altitude (Nestle et al., 1999).

Prevalences among cohorts of individuals were compared using contingency table analysis as described by Zar (1999).

\section{RESULTS}

Eight (3.8\%) of 209 individuals (15 preschool males, 9 pre-school females, 31 schoolaged males, 31 school-aged females, 24 adult males, 55 adult females, 17 senior males, 21 senior females, one male of an undetermined age, and five females of undetermined age) examined for geohelminth infection were determined to be infected with A. lumbricoides, T. trichiura, or hookworms. All infections were categorized as light. Two (1.0\%) individuals, an adult female and a senior male, were infected with $A$. lumbricoides. Infection intensities were 24 and 700 epg respectively. Four (1.9\%) individuals, one school-aged male, one school-aged female, one adult male, and one senior male were infected with $T$. trichiura. Infection intensities were 96, 28, 168, and 24 epg respectively. Two (1.0\%) individuals, a school-aged female and an adult female were infected with hookworm. Infections intensity was 24 epg in both instances. Data are summarized in Table 1. Chi-square analysis comparing overall prevalence of infection with geohelminths between the 2010 and 2017 data (Richardson et al., 2011 a,b) revealed significant decreases for each species examined and combined geohelminths as follows: A. lumbricoides $\left(\mathrm{X}^{2}=\right.$ 6.34; 1 d.f.; $\mathrm{p}=0.12)$, T. trichiura $\left(\mathrm{X}^{2}=25.41\right.$; 1 d.f.; $\mathrm{p}<0.00001)$, hookworm $\left(\mathrm{X}^{2}=7.19 ; 1\right.$ d.f.; $\mathrm{p}=0.0073)$, and combined geohelminths $\left(X^{2}=28.75 ; 1\right.$ d.f.; $\left.p<0.00001\right)$. Prevalence data for 2007, 2010, and 2017 are summarized in Figure 1. There were too few infected individuals in the current survey to provide meaningful analysis regarding infection intensities between cohorts and previous years. Nevertheless, a substantial decrease in intensity is evident between 2010 and 2017.

Hemoglobin levels were measured for 210 individuals, of which $62(29.5 \%)$ were anemic. No individual was severely anemic. Data are summarized in Table 2 along with comparative data from earlier surveys (Richardson et al., 2011b).

In 2017, in Bawa, overall 6 (2.4\%) of the 247 individuals examined were characterized as malnourished based on BMI, 1 pre-school female, 1 adult female, 2 senior females, and 2 senior males. No individual was categorized as severely malnourished based on BMI. In 2010, 11 (5.0\%) of 220 individuals examined were categorized as malnourished, 1 
adolescent male, 3 adolescent females, 2 adult females, 3 senior males, and 2 senior females. Likewise, no one was categorized as severely malnourished in 2010. In 2007, 23 (8.6\%) of 269 individuals were categorized as malnourished, 2 pre-school females, 4 preschool males, 4 adolescent females, 2 adolescent males, 4 adult females, 4 senior females, and 3 senior males. Of these, 4 individuals constituting $1.8 \%$ of the population were considered severely malnourished, 3 preschool males, and 1 adolescent male. Chisquare analysis revealed no significant difference in the relative numbers of malnourished individuals between 2010 and 2017. Likewise, Richardson et al. (2011b) detected no significant difference in the relative numbers of malnourished individuals between 2007 and 2010. However, chi-square analysis did reveal a significant decrease in the relative number of malnourished individuals between 2007 and $2017\left(\mathrm{X}^{2}=9.10\right.$; 1 d.f.; $\mathrm{p}=$ 0.0026). Data are graphically represented in Figure 2.

In 2017, among children and adolescents, 5-19 years of age, 8 (7.8\%) of 103 individuals were categorized as stunted based on WHO height for age standards. Five (9.1\%) of 55 males and $3(6.3 \%)$ of 48 females were stunted. Chi-square analysis revealed no significant difference in the relative number of stunted individuals $\left(\mathrm{X}^{2}=1.64 ; 1\right.$ d.f. $)$ between genders. Of these, $3(5.5 \%)$ of the 55 males constituting $2.9 \%$ of the overall sample were severely stunted. In 2010, 41 (36.3\%) of 113 individuals were categorized as stunted. Of these, 20 constituting $17.7 \%$ of the sample were severely stunted. Chi-square analysis conducted between the data for 2010 and 2017 revealed significant decreases in the relative number of stunted individuals $\left(\mathrm{X}^{2}=24.9 ; 1\right.$ d.f.; $\mathrm{p}<0.00001)$ and the relative number of severely stunted individuals $\left(\mathrm{X}^{2}=12.38 ; 1\right.$ d.f.; $\mathrm{p}=0.00043)$. In 2007, $52(43.0 \%)$ of 121 children and adolescents were categorized as stunted. Of these, 20 constituting $16.3 \%$ of the sample were severely stunted. Chi-square analysis conducted by Richardson et al. (2011b) revealed no significant difference in the relative number of stunted or severely stunted children and adolescents between 2007 and 2010. Data are graphically represented in Figure 3.

In 2017, among children 2-10 years of age, $3(5.9 \%)$ of 51 were underweight or severely underweight based on WHO weightfor-age standards. One $(2.0 \%)$ of the 51 children, a boy, was severely underweight. Chi-square analysis revealed no significant difference between genders in weight-for-age $\left(\mathrm{X}^{2}=0.41 ; 1\right.$ d.f.). In 2010, 23 (41.1\%) of 56 children were underweight or severely underweight with $9(17.6 \%)$ of the 51 being severely underweight. Chi-square analysis conducted between the data for 2010 and 2017 revealed significant decreases in the relative number of underweight children $\left(X^{2}=18.00 ; 1\right.$ d.f.; $p<0.000022$ ) and the relative number of severely underweight children $\left(\mathrm{X}^{2}=6.27 ; 1\right.$ d.f.; $\mathrm{p}=0.012)$. In 2007, 31 (35.6\%) of 87 children were categorized as underweight or severely underweight. Chi-square analysis conducted by Richardson et al. (2011b) revealed no significant difference in the relative number of underweight children between 2007 and 2010. Data are graphically represented in Figure 4.

In 2017 , none of the 18 children (2-5 years), 12 boys and 6 girls, were categorized as wasted based on WHO standards of weight for height. Likewise, none of 13 children examined in 2010 were wasted; however, in 2007,2 (5.9\%) of 34 children were categorized as wasted. 
Table 1: Prevalence [number infected/number sampled (\%)], mean intensity \pm SE given in eggs per gram of feces (epg) of Ascaris lumbricoides, Trichuris trichiura, hookworm, and combined geohelminths in 2017.

\begin{tabular}{|c|c|c|c|c|c|}
\hline Cohort & & $\begin{array}{l}\text { Ascaris } \\
\text { lumbricoides }\end{array}$ & $\begin{array}{l}\text { Trichuris } \\
\text { trichiura }\end{array}$ & Hookworm & $\begin{array}{l}\text { Overall } \\
\text { Geohelminths }\end{array}$ \\
\hline$\hat{0}$ & \# infected/\# sampled (\%) & $0 / 15(0.0 \%)$ & $0 / 15(0.0 \%)$ & $0 / 15(0.0 \%)$ & $0 / 15(0.0 \%)$ \\
\hline \multirow[t]{2}{*}{ Preschool } & Mean intensity $( \pm \mathrm{SE})$ & --- & --- & --- & n/a------ \\
\hline & Range & --- & --- & --------- & $\mathrm{n} / \mathrm{a}$ \\
\hline q & \# infected/\# sampled (\%) & $0 / 9(0.0 \%)$ & $0 / 9(0.0 \%)$ & $0 / 9(0.0 \%)$ & $0 / 9(0.0 \%)$ \\
\hline \multirow[t]{2}{*}{ Preschool } & Mean intensity $( \pm \mathrm{SE})$ & --- & --- & --- & $\mathrm{n} / \mathrm{a}$ \\
\hline & Range & --- & --- & --------- & $\mathrm{n} / \mathrm{a}$ \\
\hline Overall & \# infected/\# sampled (\%) & $0 / 24(0.0 \%)$ & $0 / 24(0.0 \%)$ & $0 / 24(0.0 \%)$ & $0 / 24(0.0 \%)$ \\
\hline \multirow[t]{2}{*}{ Preschool } & Mean intensity $( \pm \mathrm{SE})$ & --- & --- & --- & $\mathrm{n} / \mathrm{a}$ \\
\hline & Range & --- & --- & --------- & $\mathrm{n} / \mathrm{a}$ \\
\hline \multirow{3}{*}{$\begin{array}{l}\hat{\delta} \text { School- } \\
\text { aged }\end{array}$} & \# infected/\# sampled (\%) & $0 / 31(0.0 \%)$ & $1 / 31(3.2 \%)$ & $0 / 31(0.0 \%)$ & $1 / 31(3.2 \%)$ \\
\hline & Mean intensity $( \pm \mathrm{SE})$ & --- & $96 \pm 0$ & --- & $\mathrm{n} / \mathrm{a}$ \\
\hline & Range & --- & $96-96$ & ------- & $\mathrm{n} / \mathrm{a}$ \\
\hline \multirow{3}{*}{$\begin{array}{l}+ \text { School- } \\
\text { aged }\end{array}$} & \# infected/\# sampled (\%) & $0 / 31(0.0 \%)$ & $1 / 31(3.2 \%)$ & $1 / 31(3.2 \%)$ & $1 / 31(3.2 \%)$ \\
\hline & Mean intensity $( \pm \mathrm{SE})$ & --- & $28 \pm 0$ & $24 \pm 0$ & $\mathrm{n} / \mathrm{a}$ \\
\hline & Range & --- & $28-28$ & $24-24$ & $\mathrm{n} / \mathrm{a}$ \\
\hline \multirow{3}{*}{$\begin{array}{l}\text { Overall } \\
\text { School- } \\
\text { aged }\end{array}$} & \# infected/\# sampled (\%) & $0 / 62$ & $2 / 62(3.2 \%)$ & $1 / 62(1.6 \%)$ & $3 / 62(4.8 \%)$ \\
\hline & Mean intensity $( \pm \mathrm{SE})$ & --- & $62 \pm 34$ & $24 \pm 0$ & $\mathrm{n} / \mathrm{a}$ \\
\hline & Range & --- & $28-96$ & $24-24$ & $\mathrm{n} / \mathrm{a}$ \\
\hline \multirow[t]{3}{*}{$\hat{\sigma}$ Adult } & \# infected/\# sampled (\%) & $0 / 24(0.0 \%)$ & $1 / 24(4.1 \%)$ & $0 / 24(0.0 \%)$ & $1 / 24(4.1 \%)$ \\
\hline & Mean intensity $( \pm \mathrm{SE})$ & --- & $168 \pm 0$ & --- & $\mathrm{n} / \mathrm{a}$ \\
\hline & Range & --- & $168-168$ & --- & $\mathrm{n} / \mathrm{a}$ \\
\hline \multirow[t]{3}{*}{ q Adult } & \# infected/\# sampled (\%) & $1 / 55(1.8 \%)$ & $0 / 55(0.0 \%)$ & $1 / 55(1.8 \%)$ & $2 / 55(3.6 \%)$ \\
\hline & Mean intensity $( \pm \mathrm{SE})$ & $24 \pm 0$ & --- & $24 \pm 0$ & $\mathrm{n} / \mathrm{a}$ \\
\hline & Range & $24-24$ & --- & $24-24$ & $\mathrm{n} / \mathrm{a}$ \\
\hline \multirow{3}{*}{$\begin{array}{l}\text { Overall } \\
\text { Adult }\end{array}$} & \# infected/\# sampled (\%) & $1 / 79(1.3 \%)$ & $1 / 79(1.3 \%)$ & $1 / 79(1.3 \%)$ & $3 / 79(3.8 \%)$ \\
\hline & Mean intensity $( \pm \mathrm{SE})$ & $24 \pm 0$ & $168 \pm 0$ & $24 \pm 0$ & $\mathrm{n} / \mathrm{a}$ \\
\hline & Range & $24-24$ & $168-168$ & $24-24$ & $\mathrm{n} / \mathrm{a}$ \\
\hline \multirow[t]{3}{*}{ Senior } & \# infected/\# sampled (\%) & $1 / 17(5.9 \%)$ & $1 / 17(5.9 \%)$ & $0 / 17(0.0 \%)$ & $2 / 17(11.8 \%)$ \\
\hline & Mean intensity $(+\mathrm{SE})$ & $700 \pm 0$ & $24 \pm 0$ & --- & $\mathrm{n} / \mathrm{a}$ \\
\hline & Range & $700-700$ & $24-24$ & --- & $\mathrm{n} / \mathrm{a}$ \\
\hline \multirow[t]{3}{*}{$q$ Senior } & \# infected/\# sampled (\%) & $0 / 21(0.0 \%)$ & $0 / 21(0.0 \%)$ & $0 / 21(0.0 \%)$ & $0 / 21(0.0 \%)$ \\
\hline & Mean intensity $(+\mathrm{SE})$ & --- & --- & --- & $\mathrm{n} / \mathrm{a}$ \\
\hline & Range & --- & --- & --- & $\mathrm{n} / \mathrm{a}$ \\
\hline \multirow{3}{*}{$\begin{array}{l}\text { Overall } \\
\text { senior }\end{array}$} & \# infected/\# sampled (\%) & $1 / 38(2.6 \%)$ & $1 / 38(2.6 \%)$ & $0 / 38(0.0 \%)$ & $2 / 38(5.3 \%)$ \\
\hline & Mean intensity $( \pm \mathrm{SE})$ & $700 \pm 0$ & $8 \pm 0$ & --- - - & $\mathrm{n} / \mathrm{a}$ \\
\hline & Range & $700-700$ & $8-8$ & --- & $\mathrm{n} / \mathrm{a}$ \\
\hline \multirow[t]{3}{*}{$\widehat{O}$ Overall } & \# infected/\# sampled (\%) & $1 / 87(1.1 \%)$ & $3 / 87(3.4 \%)$ & $0 / 87(0.0 \%)$ & $4 / 87(4.6 \%)$ \\
\hline & Mean intensity $(\underline{+} \mathrm{SE})$ & $700 \pm 0$ & $96 \pm$ & --- & $\mathrm{N} 2244 / / \mathrm{a}$ \\
\hline & Range & $24-92,232$ & $24-168$ & --- & $\mathrm{n} / \mathrm{a}$ \\
\hline \multirow[t]{3}{*}{ + Overall } & \# infected/\# sampled (\%) & $1 / 116(0.86 \%)$ & $1 / 116(0.86 \%)$ & $2 / 116(1.7 \%)$ & $4 / 116(3.4 \%)$ \\
\hline & Mean intensity $( \pm \mathrm{SE})$ & $24 \pm 0$ & $28 \pm 0$ & $24 \pm 0$ & $\mathrm{a}$ \\
\hline & Range & $24-24$ & $28-28$ & $24-24$ & $\mathrm{n} / \mathrm{a}$ \\
\hline \multirow[t]{3}{*}{ OVERALL } & \# infected/\# sampled (\%) & $2 / 209 *(1.0 \%)$ & $4 / 209 *(1.9 \%)$ & $2 / 209 *(1.0 \%)$ & $8 / 209 *(3.8 \%)$ \\
\hline & Mean intensity $( \pm S E)$ & $362 \pm 338$ & $79 \pm 34$ & $24 \pm 0$ & $\mathrm{n} / \mathrm{a}$ \\
\hline & Range & $24-700$ & 24-168 & $24-24$ & $\mathrm{n} / \mathrm{a}$ \\
\hline
\end{tabular}

*This sample size of 209 individuals includes 1 male and 5 females of indeterminate age, who were not infected with any geohelminths, but could not be verified to a specific cohort. 


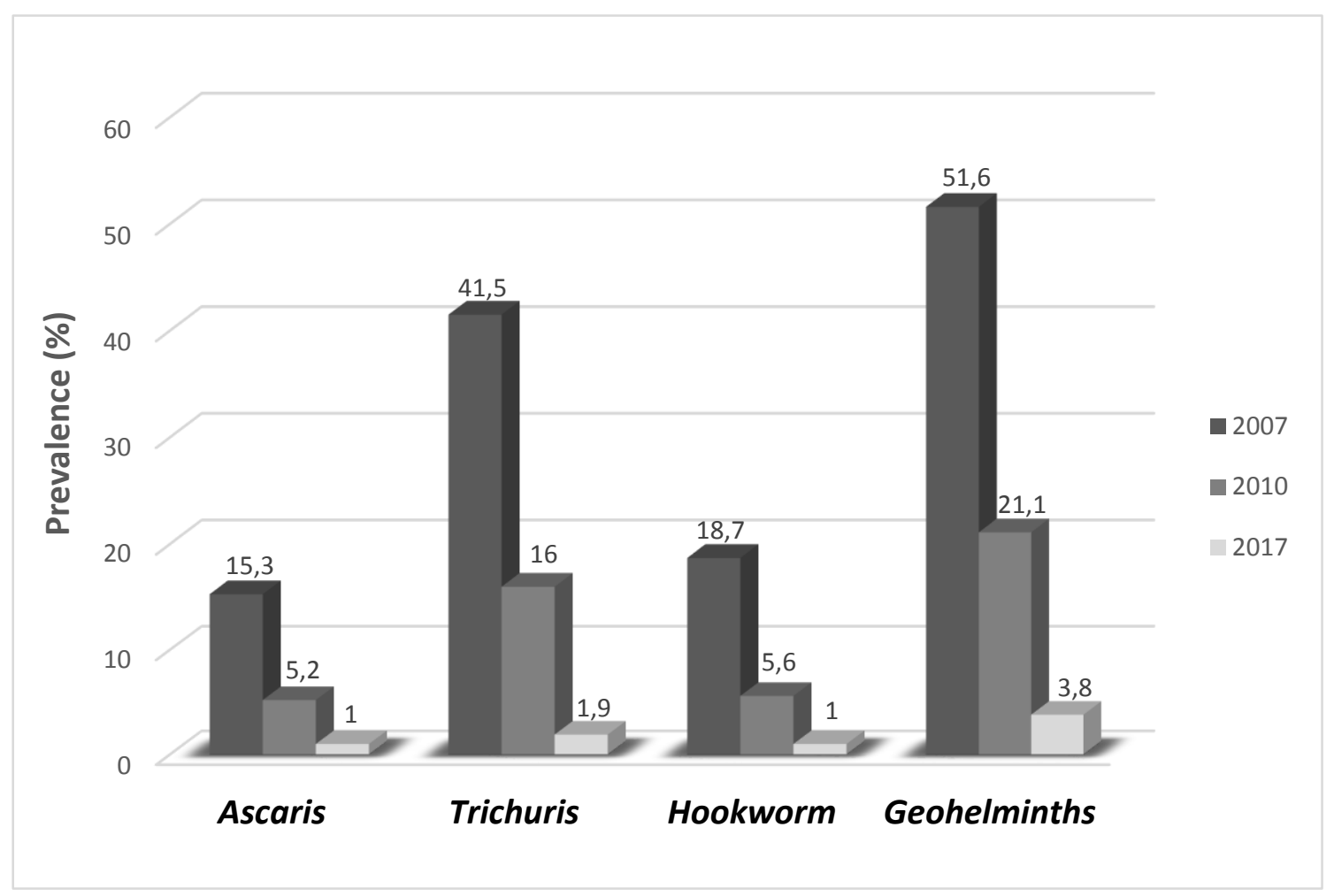

Figure 1: Comparison of prevalences of Ascaris lumbricoides, Trichuris trichiura, hookworms, and combined geohelminths between 2007, 2010 and 2017 for the combined population of Bawa.

Table 2: Incidence (number anemic/number sampled (\%)), mean intensity $( \pm \mathrm{SE})$ given as hemoglobin/dl of whole blood, and incidence of severe anemia $(\leq 7 \mathrm{~g}$ hemoglobin/dl) in 2007, 2010, and 2017.

\begin{tabular}{lllll}
\hline $\begin{array}{l}\text { Age } \\
\text { (years) }\end{array}$ & & $\mathbf{2 0 0 7}$ & $\mathbf{2 0 1 0}$ & $\mathbf{2 0 1 7}$ \\
\hline$<\mathbf{5}$ & \# anemic/\# sampled & $26 / 30(86.7 \%)$ & $9 / 13(69.2 \%)$ & $5 / 20(25.0 \%)$ \\
& Mean Hbg $( \pm$ SE) & $9.4 \pm 0.3$ & $9.5 \pm 0.8$ & $9.6 \pm 0.6$ \\
& \# Severely anemic $(\%)$ & $3(10.0 \%)$ & $0(0.0 \%)$ & $0(0.0 \%)$ \\
\hline $\mathbf{5 - 1 1}$ & \# anemic/\# sampled & $60 / 67(89.6 \%)$ & $36 / 69(52.2 \%)$ & $8 / 31(25.8 \%)$ \\
& Mean Hbg $( \pm$ SE) & $9.6 \pm 0.2$ & $11.4 \pm 0.2$ & $10.8 \pm 0.2$ \\
& \# Severely anemic $(\%)$ & $4(6.0 \%)$ & $0(0.0 \%)$ & $0(0.0 \%)$ \\
\hline$>\mathbf{1 1}$ & \# anemic/\# sampled & $108 / 159(68.0 \%)$ & $60 / 132(45.5 \%)$ & $49 / 159(30.8 \%)$ \\
& Mean Hbg $( \pm$ SE) & $11.0 \pm 0.2$ & $11.4 \pm 2$ & $11.3 \pm 0.1$ \\
& \# Severely anemic $(\%)$ & $2(1.2 \%)$ & $1(0.8 \%)$ & $0(0.0 \%)$ \\
\hline Overall & \# anemic/\# sampled & $194 / 256(75.8 \%)$ & $105 / 214(49.1 \%)$ & $62 / 210(29.5 \%)$ \\
& Mean Hbg $( \pm$ SE) & $10.5 \pm 0.1$ & $11.9 \pm 0.1$ & $11.1 \pm 0.1$ \\
& \# Severely anemic $(\%)$ & $9(3.5 \%)$ & $1(0.5 \%)$ & $0(0.0 \%)$ \\
\hline
\end{tabular}




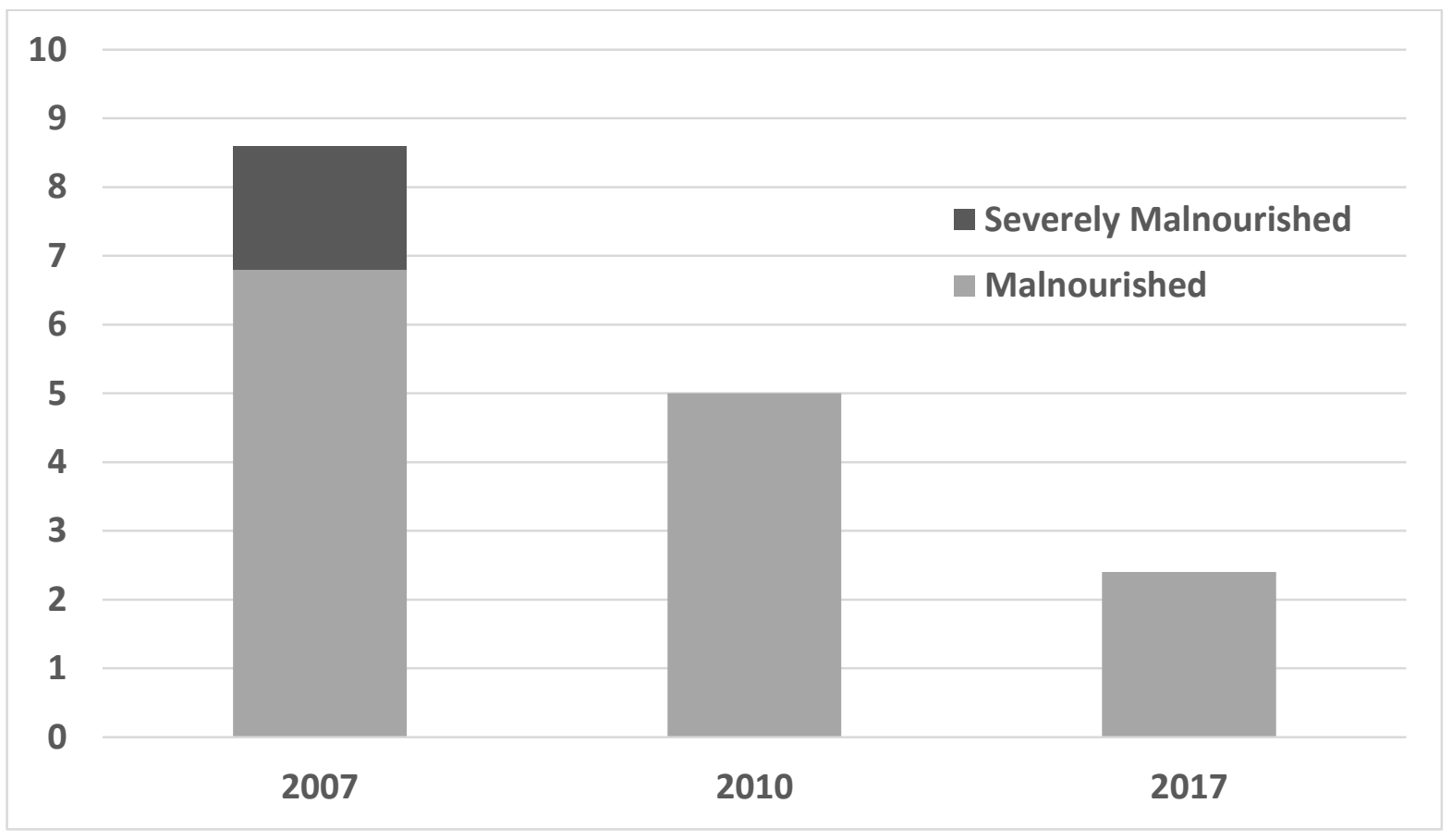

Figure 2: Comparisons of prevalences of malnourishment and severe malnourishment between 2007, 2010, and 2017 in Bawa, Cameroon.

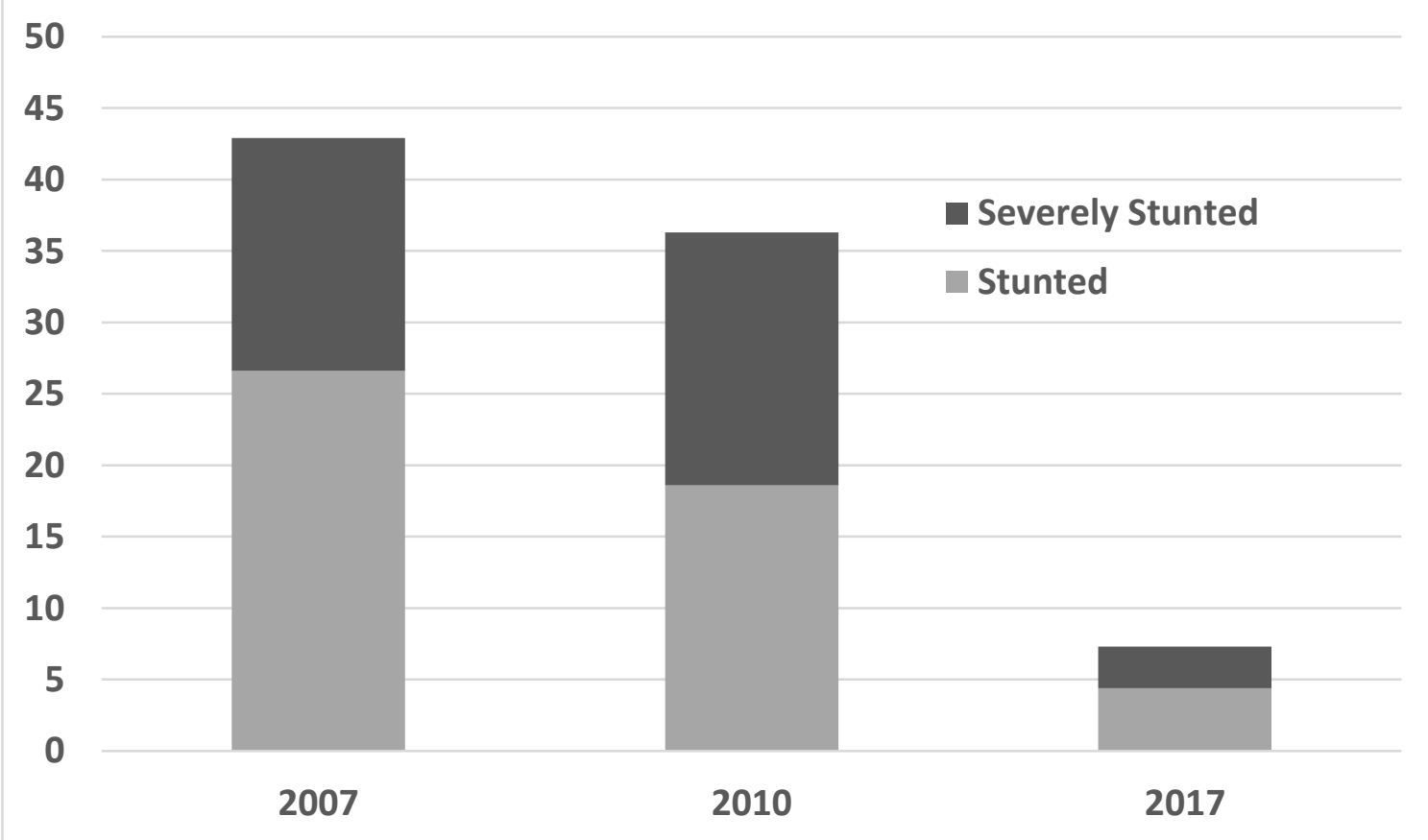

Figure 3: Comparisons of prevalences of stunted and severely stunted individuals (aged 5-19) between 2007, 2010, and 2017 in Bawa, Cameroon. 


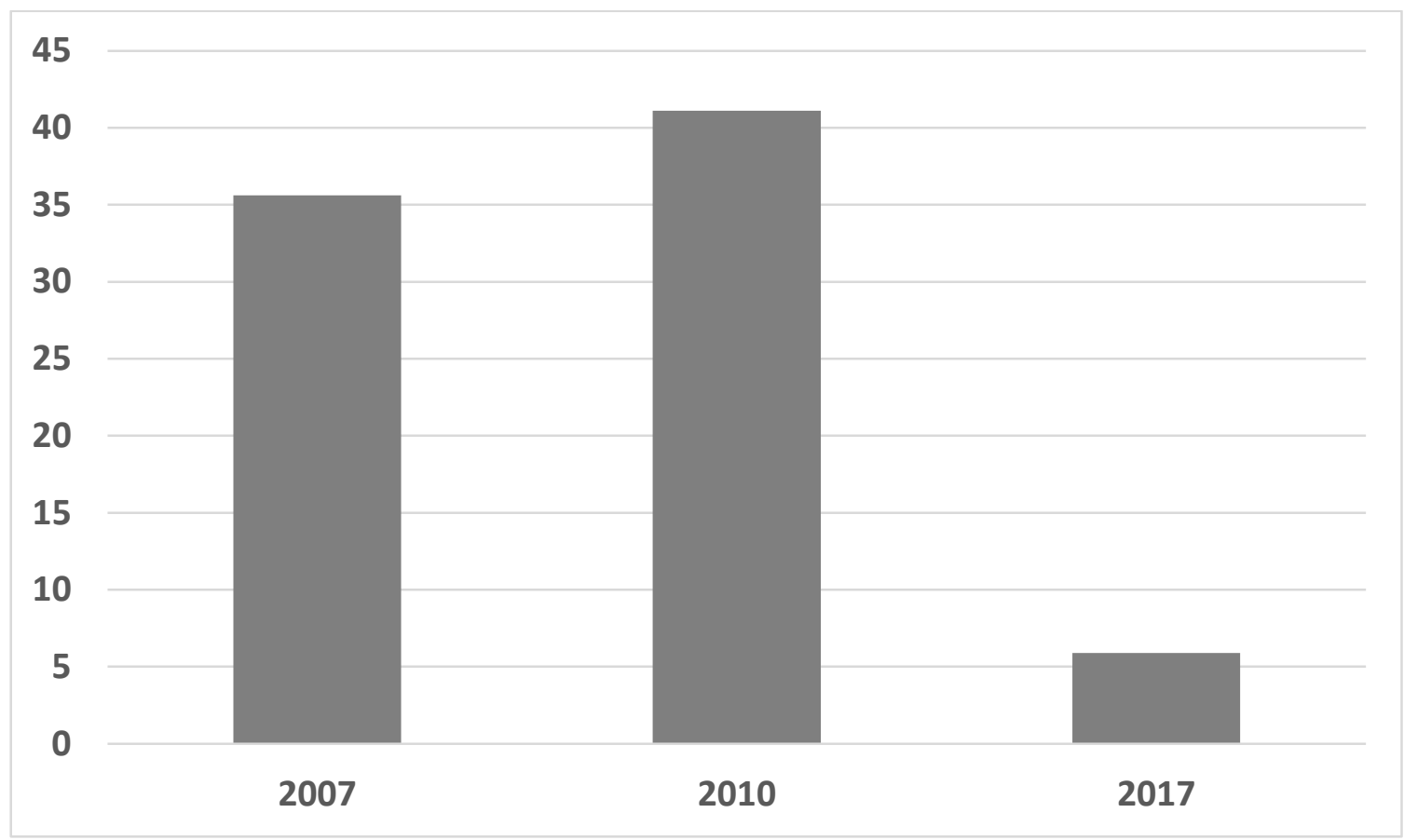

Figure 4: Comparisons of prevalences of underweight individuals (aged 2-10) between 2007, 2010, and 2017 in Bawa, Cameroon.

\section{DISCUSSION}

This study provides an assessment of interventions implemented by BHI in Bawa, including provision of insecticide treated bed nets, water filters, sanitary latrines, a geohelminth control program utilizing the anthelmintic albendazole, and a rigorous education program focused on basic matters of sanitation and hygiene. All metrics indicate substantial improvement in the overall health of the citizens of Bawa between 2007 and 2017, evidenced by decreases in the occurrence of anemia (Table 2), and prevalence of malnourished, undernourished and stunted individuals (Figures 2-4). Particularly noteworthy is the reduction in the prevalence and intensity of geohelminths (Figure 1), which may have a profound impact on the overall health and well-being of persons living in endemic areas (Yapi et al., 2017; Orsot et al., 2018). Given the high degree of success realized in the control of geohelminth infections through the treatment program initiated by BHI, it was determined to reduce the number of treatments from 2 per year (June and December), to once per year (June) based on recommendations of the World Health Organization (2002), beginning in 2018. The general recommendations are that in areas where the prevalence of geohelminth infection is greater than $70 \%$ and more than $10 \%$ moderate and heavy infections, 2-3 treatments per year are recommended. When the prevalence is between $40-60 \%$ and the incidence of moderate and heavy infections is less than $10 \%$, treatment is recommended once 
per year. Advantages of optimizing the number of treatments to the minimal level required to achieve community control of geohelminth infection, include reduced cost, reduced logistic complexity, and foremost, reduced risk of development of resistance to anthelmintics (Albonico et al., 2003; Hotez et al., 2006; Richardson et al., 2011b).

\section{Conclusion}

These data strongly suggest that public health interventions implemented by the Bawa Health Initiative have been exceedingly effective in reducing the burden of disease and increasing the overall well-being of the citizens of Bawa, Cameroon and surrounding villages. Additionally, these data provide an important hallmark in continuing to monitor the effectiveness of the activities of the Bawa Health Initiative subsequent to opening the Sophie Awounke Community Health Center in December 2017.

\section{COMPETING INTERESTS}

The authors declare that they have no competing interests.

\section{AUTHORS' CONTRIBUTIONS}

DJR designed the study and directed data acquisition, data analyses, and wrote the text of the manuscript. JG worked with DJR in data acquisition. PT is the Chief Medical Officer of BHI and oversees and coordinates all treatment and surveillance efforts. BD has been an integral part of the design and conduct of this entire disease control program since its inception in 2005. He was instrumental in acquiring funds and arranging logistic support making this work possible. BD critically revised the manuscript.

\section{ACKNOWLEDGEMENTS}

Erik Davis, volunteer nurse for BHI provided invaluable support in the planning and conduct of this study. Sara N. Karr, School of Health Sciences at Quinnipiac University provided valuable assistance in data analysis and in the preparation of this manuscript. The contribution of Menoua Division health authorities and the chief of Bawa, and the participation of the population are greatly appreciated. The authors are grateful to its Board of Directors of the Bawa Health Initiative for their support.

\section{REFERENCES}

Callahan KD. 2010. Prevalence of waterborne protozoal parasites in two rural villages in the West Province of Cameroon, Africa. M.S. thesis. Quinnipiac University, Hamden, Connecticut. p. 73.

Caulfield LE, Richard SA, Rivera JA, Musgrove P, Black RE. 2006. Stunting, wasting, and micronutrient deficiency disorders. In Disease Control Priorities in Developing Countries ( $2^{\text {nd }}$ edn), Jamison DT, Breman JG, Measham AR, Aleyne G, Claeson M, Evans DB, Jha P, Mills A, Musgrove P (eds.). Oxford University Press: New York; 551-567.

de Onis M, Onyango AW, Borghi E, Siyam A, Nishida C, Siekmann J. 2007. Development of a WHO growth reference for school-aged children and adolescents. Bull. World Health Organ., 85(9): 660-667. DOI: 10.2471/BLT.07.043497

Hotez PJ, Bundy DA, Beegle K, Brooker S, Drake L, de Silva N, Montresor A, Engels D, Jukes M, Chitsulo L, Chow J, Laxminarayan R, Michaud C, Bethony J, Correa-Oliveria R, Shuhua X, Fenwick A, Savioli L. 2006. Helminth infections: Soil-transmitted helminth infections and 
schistosomiasis. In Disease Control Priorities in Developing Countries $\left(2^{\text {nd }}\right.$ edn), Jamison DT, Breman JG, Measham AR, Aleyne G, Claeson M, Evans DB, Jha P, Mills A, Musgrove P (eds.). Oxford University Press: New York; 467482.

Letah Nzouebet WA, Soh Kengne E, Djumyom Wafo GV, Wanda C, Rechenburg A, Kengne Noumsi IM. 2019. Assessment of the faecal sludge management practices in households of a sub-Saharan Africa urban area and the health risks associated: the case study of Yaoundé, Cameroon. Int. J. Biol. Chem. Sci., 13(5): 1-23. DOI: https://dx.doi.org/10.4314/ijbcs.v13i5.1S

Montresor A, Crompton DWT, Gyorkos TW, Savioli L. 2002. Helminth Control in School-age Children: A Guide for Managers of Control Programmes. World Health Organization: Geneva, Switzerland.

Nestle P, Melara A, Rosado J, Mora JO. 1999. Vitamin A deficiency and anemia among children 12-71 months old in Honduras. Rev. Panam. Salud Publica, 6(1):34-43. DOI: 10.1590/5102049891999000600005

Onana J, Fobane JL, Biye EH, Tchatchouang EN, Mbolo, MMA. 2019. Habitats naturels des écosystèmes du Cameroun. Int. J. Biol. Chem. Sci., 13(7): 3247-3265. DOI:

https://dx.doi.org/10.4314/ijbcs.v13i7.22

Orsot MN, Meite A, N'Guessan NA, Dje NN, Ouattara M, Coulibaly JT, Assare RK, Diakite NR, Mama AD, Dje LMA, N'Goran EK. 2018. Detailed distribution of schistosomiasis and soil-transmitted helminthiasis among schoolchildren in the Bélier and Marahoué regions, central Côte d'Ivoire: a tool for an efficient control. Int. J. Biol. Chem. Sci., 12(4): 1532-1542.

DOI: https://dx.doi.org/10.4314/ijbcs.v12i4.I

Richardson DJ, Gross J, Smith MC. 2008. Comparison of Kato-Katz direct smear and sodium nitrate flotation for detection of geohelminth infections. Comp. Parasitol., 75(2): 339-341. DOI: $10.1654 / 4340.1$

Richardson DJ, Richardson KR, Callahan KD, Gross J, Tsekeng P, Dondji B, Richardson KE. 2011a. Geohelminth infection in rural Cameroonian villages. Comp. Parasitol., 78(1):161-179. DOI: $10.1654 / 4444.1$

Richardson DJ, Richardson KR, Richardson KE, Gross J, Tsekeng P, Dondji B, Foulefack S. 2011b. Malaria, intestinal parasitic infection, anemia, and malnourishment in rural Cameroonian villages with an assessment of early interventions. J. Ark. Acad. Sci., 65(1): 72-97.

Stoltzfus RJ, Dreyfuss ML. 1998. Guidelines for the use of iron supplements to prevent and treat iron deficiency anemia. International Life Sciences Institute: Washington, D.C.

Tchuinkam T, Simard F, Lélé-Defo E, TénéFossog B, Tateng-Ngouateu A, AntonioNkondjio C, Mpoame M, Toto J, Njin T, Fontenille D, Awono-Ambéné H. 2010. Bionomics of anopheline species and malaria transmission dynamics along an altitudinal transect in western Cameroon. BMC Infect. Dis., 10: 119. DOI: 10.1186/1471-2334-10-119

WHO. 1995. Physical status: The use and interpretation of anthropometry. WHO Technical Series Report 854. World Health Organization, Geneva.

WHO. 2002. Prevention and control of schistosomiasis and soil-transmitted 
helminthiasis. WHO Technical Series Report 912. World Health Organization, Geneva.

WHO. 2006. WHO child growth standards: Length/height-for-age, weight-for-age, weight-for-length, weight-for-height and body mass index-for-age: Methods and development. World Health Organization, Geneva.

WHO and UNICEF. 2009. WHO growth standards and the identification of severe acute malnutrition in infants and children. World Health Organization, Geneva.
WHO and UNICEF. 2010. Progress on sanitation and drinking-water: 2010 update. World Health Organization, Geneva.

Yapi GY, Touré M, Sarr MD, Abo N, Diabaté S. 2017. The impact of irrigated rice on the transmission of schistosomiasis and geohelminthiasis in Niakaramandougou, Côte d'Ivoire. Int. J. Biol. Chem. Sci., 11(4): $\quad$ 1400-1412. DOI: http://dx.doi.org/10.4314/ijbcs.v11i4.1.

Zar JH. 1999. Biostatistical Analysis (4 ${ }^{\text {th }}$ edn). Prentice-Hall: Upper Saddle River, New Jersey. 